\title{
Effects of Escin on Oxidative Stress and Apoptosis of H9c2 Cells Induced by $\mathrm{H}_{2} \mathrm{O}_{2}$
}

\author{
Peng Qiao, ${ }^{1}$ Baokun Zhang, ${ }^{2}$ Xueni Liu $\left(\mathbb{D}^{3}{ }^{3}\right.$ Jie $\mathrm{Xu}^{4}{ }^{4}$ and Xuehan Li ${ }^{5}$ \\ ${ }^{1}$ Department of Traditional Chinese Medicine, Yantaishan Hospital, Yantai, China \\ ${ }^{2}$ Public Health, The University of Sheffield, UK \\ ${ }^{3}$ Critical Care Medicine, PLA Rocket Force Characteristic Medical Center, Beijing, China \\ ${ }^{4}$ Department of Medical Security Center, PLA Rocket Force Characteristic Medical Center, Beijing, China \\ ${ }^{5}$ Department of Geriatric, Liaocheng People's Hospital, Liaocheng, China
}

Correspondence should be addressed to Xueni Liu; 317959274@qq.com

Received 20 October 2021; Accepted 14 December 2021; Published 27 January 2022

Academic Editor: Simona Pichini

Copyright (c) 2022 Peng Qiao et al. This is an open access article distributed under the Creative Commons Attribution License, which permits unrestricted use, distribution, and reproduction in any medium, provided the original work is properly cited.

Objective. Myocardial infarction (MI) is a serious heart health problem in the world with a high mortality rate. Our study is mainly aimed at validating the antioxidative stress and antiapoptotic effects of escin in a $\mathrm{H}_{2} \mathrm{O}_{2}$-induced cardiomyocyte injury model. Methods. H9c2 cells were divided into control group, $\mathrm{H}_{2} \mathrm{O}_{2}$ treatment group, and $\mathrm{H}_{2} \mathrm{O}_{2}$ +escin group. We studied the effect of escin on $\mathrm{H} 9 \mathrm{c} 2$ cells and its mechanism by flow cytometry, real-time PCR, CCK- 8 assay and Western blot. Cell morphology was observed by cell staining and optical microscopy. Results. We found that the level of reactive oxygen species (ROS) in the $\mathrm{H}_{2} \mathrm{O}_{2}$ treatment group was significantly elevated, while the high level of ROS was significantly reversed after treatment with escin. The protein levels of SOD1, SOD2, Bcl-2, and $\mathrm{I} \kappa \mathrm{B}-\alpha$ in the $\mathrm{H}_{2} \mathrm{O}_{2}$ treatment group were significantly decreased compared with the $\mathrm{H}_{2} \mathrm{O}_{2}+$ escin group, and the Bax, TNF- $\alpha$, IL- $1 \beta$, p65, and $\mathrm{I} \kappa \mathrm{K} \alpha$ protein expressions were greatly higher than those in the $\mathrm{H}_{2} \mathrm{O}_{2}+$ escin group. And the results of PCR were also consistent with those. TUNEL-positive cells also decreased significantly when treated with escin. Flow cytometry showed that the percentage of apoptotic cells decreased greatly after treatment of escin. Through IL-1 $\beta$ immunofluorescence, the fluorescence intensity of the $\mathrm{H}_{2} \mathrm{O}_{2}$ treatment group was greatly higher compared with that of the control group, but escin reversed this effect. Conclusions. These results indicated that escin inhibits $\mathrm{H}_{2} \mathrm{O}_{2}$-induced $\mathrm{H} 9 \mathrm{c} 2$ cell apoptosis, oxidative stress, and inflammatory responses via the NF- $\kappa \mathrm{B}$ signaling pathway.

\section{Introduction}

Myocardial infarction is a serious cardiovascular disease in the world. It is mainly due to coronary atherosclerosis which leads to narrowing of the lumen and causes damage to the myocardium innervated by blocked blood vessels [1]. Due to ischemia and hypoxia, myocardial infarction produces excessive ROS, which destroys surrounding myocardial tissue and further causes apoptosis of cardiomyocytes [2]. It is well known that cardiomyocytes are nonrenewable, and oxidative stress and apoptosis of the myocardium can lead to the death of some myocardium, eventually leading to deterioration of heart function and even death. The existing treatments are mainly to achieve recanalization of blood vessels but cannot reverse the apoptosis of cardiomyocytes, and myocardial ischemia and reperfusion may aggravate oxidative stress [3]. Therefore, new treatments are urgently needed to inhibit myocardial oxidative stress and apoptosis in the early stages of myocardial infarction.

Escin is a pentacyclic triterpenoid saponin extracted from the dried mature seeds of the horse chestnut [4]. At present, there are many studies describing the role of escin in various histopathophysiology, including ovary, nervous system, and skin. Many people have also studied its role in tumors. Selvakumar et al. [5] believed that escin plays an antiapoptotic and antioxidative stress in Parkinson's disease and can improve the motor function of 
patients. Wang et al. [6] believed that escin can play an antioxidative stress on retinal pigment epithelial cells. Cheng et al. [7] suggested that escin can regulate apoptosis in ovarian cancer. However, the effect of escin on cardiomyocytes has not been studied.

In this study, $\mathrm{H}_{2} \mathrm{O}_{2}$-induced myocardial cell injury model was adopted to investigate whether escin can play an antioxidative, antiapoptotic, and anti-inflammatory role and its potential mechanism of action. Our results showed that escin may provide a potential new treatment for MI.

\section{Materials and Methods}

2.1. Cell Culture. Dulbecco's Modified Eagle's Medium (MCE, Nanjing, China) complemented with $10 \%$ fetal bovine serum (FBS) (MCE, Nanjing, China) was used to culture $\mathrm{H} 9 \mathrm{c} 2$ cells in 37 degrees Celsius incubator under 5\% $\mathrm{CO}_{2}$. When the cells grew to about $80 \%$ confluence, they began to be plated and treated with $\mathrm{H}_{2} \mathrm{O}_{2}(100 \mu \mathrm{M})$ for 4 hours and escin $(10 \mu \mathrm{M})$ for 24 hours.

2.2. Drug Preparation. Escin was purchased from Tianpu Biochemical Pharmaceutical in Guangdong (Guangzhou, China). The stock solution was stored in a refrigerator at -20 degrees Celsius.

\subsection{RNA Extraction and Real-Time Polymerase Chain} Reaction (PCR). TRIzol reagent (MCE, Nanjing, China) was utilized to extract the total RNA of H9c2 cells. $0.5 \mathrm{ml}$ of TRIzol was added into each well of a 24 -well plates, and the liquid was transferred to the EP tube after grinding. Then, chloroform was added in 1/5 times of the amount of TRIzol. We let the eppendorf (EP) tubes shake, and let it stand for 5 minutes. After that, the EP tubes were centrifuged with a centrifugal force of $12000 \times \mathrm{g}$ for about 20 minutes at $4^{\circ} \mathrm{C}$. We aspirated the upper aqueous phase of the mixture obtained by centrifugation and added an equal amount of isopropanol, mixed it, and placed it at $4^{\circ} \mathrm{C}$ for 15 minutes. Then, we centrifuged the mixture at $4^{\circ} \mathrm{C}$ for 15 minutes with a centrifugal force of $12000 \times \mathrm{g}$, after which the supernatant was discarded and $1 \mathrm{~mL}$ of a $75 \%$ ethanol solution was added. The solution was centrifuged at $4{ }^{\circ} \mathrm{C}$ for 5-10 minutes with a centrifugal force of $7500 \times \mathrm{g}$, after which the supernatant was discarded and dried at room temperature, and $20 \mu \mathrm{L}$ of ribonuclease free water was added. Finally, we used NanoDropTM 8000 to measure RNA concentration.

Reverse transcription was performed using reverse transcriptase kit (MCE, Nanjing, China). Real-time PCR was performed by using Prism 7900 System. We used a $10 \mu \mathrm{L}$ reaction system in accordance with the protocol. GAPDH (MCE, Nanjing, China) was used to standardize the data. All the primers are listed in Table 1.

2.4. Western Blot. The total protein of the cells placed in a 6well plate was extracted by a protein extraction kit [8]. The protein concentration was measured by the bicinchoninic acid (BCA) method (Pierce, Rockford, IL, USA). Then, the loading buffer was added to the total protein and boiled the mixture for 7 minutes. After that, we took the same amount of total protein and performed electrophoresis with $10 \%$ sodium dodecyl sulphate-polyacrylamide gel electrophoresis (SDS-PAGE). Then, we transferred the electrophoresed protein to the polyvinylidene fluoride (PVDF, EpiZyme, Shanghai, China) membrane. 5\% concentration of skim milk was prepared with Tween-20 (TBST) to block the nonspecific antigens of the protein bands. After 2 hours, the primary antibodies were used to incubate the bands overnight (SOD1, Abcam, Cambridge, MA, USA, Rabbit, $1: 2000$; SOD2, Abcam, Cambridge, MA, USA, Rabbit, 1:2000; Bcl-2, Abcam, Cambridge, MA, USA, Mouse, 1:1000; Bax, Abcam, Cambridge, MA, USA, Mouse, $1: 1000$; TNF- $\alpha$, Abcam, Cambridge, MA, USA, Rabbit, $1: 1000$; IL-1 $\beta$, Abcam, Cambridge, MA, USA, Rabbit, 1:5000; p65, Abcam, Cambridge, MA, USA, Rabbit, $1: 1000 ; \mathrm{I} \kappa \mathrm{K} \alpha$, Abcam, Cambridge, MA, USA, Rabbit, $1: 2000$; I $\kappa$ B- $\alpha$, Abcam, Cambridge, MA, USA, Rabbit, $1: 2000$; and GAPDH, Proteintech, Rosemont, IL, USA, $1: 3000$ ), followed by incubation with secondary antibodies for 1.5 hours. After the bands were washed 3 times for 30 minutes, the protein bands were exposed by the Image $\mathrm{Lab}^{\mathrm{TM}}$ Software.

2.5. ROS Quantification. Quantification of ROS was performed using the DHR-ROS test kit (KeyGen, Shanghai, China) in accordance with the manufacturer's protocol.

2.6. Superoxide Dismutase (SOD) Activity Assay. We lysed the $\mathrm{H} 9 \mathrm{c} 2$ cells with lysate and collected and centrifuged to remove the supernatant. Detection of SOD levels in cells was performed by the SOD assay kit (KeyGen, Shanghai, China) in accordance with the protocol.

2.7. TUNEL Staining. TUNEL kit (Roche, Basel, Switzerland) was used as instructed by the manufacturer to detect the apoptotic cells. Briefly, the H9c2 cells were fixed with $4 \%$ paraformaldehyde for 20 minutes at room temperature and then treated with Triton X-100 for another 20 minutes. After that, the cells were treated with $150 \mu$ l TUNEL reaction solution at $37^{\circ} \mathrm{C}$ for 60 minutes. And the nucleus was stained with DAPI (Beyotime Biotechnology, Shanghai, China). TUNEL staining was shown by a Confocal Laser Scanning Microscope (CLSM).

2.8. Cell Counting Kit-8 (CCK-8) Assay. We placed H9c2 cells in a 96-well plate. After $\mathrm{H}_{2} \mathrm{O}_{2}$ and escin treatment, the viability of different groups of cells was examined by CCK-8 assay (Dojindo, Kumamoto, Japan) to explore the effect of escin on $\mathrm{H} 9 \mathrm{c} 2$ cells. The absorbance at $450 \mathrm{~nm}$ was detected using a microplate reader.

2.9. Flow Cytometry. $\mathrm{H} 9 \mathrm{c} 2$ cells were treated with $\mathrm{H}_{2} \mathrm{O}_{2}$ and escin as described above. The supernatant was then collected, and adherent cells were collected after digestion with trypsin. We centrifuged the cell suspension with a centrifugal force of $200 \times \mathrm{g}$ for 5 minutes, discarded the supernatant, washed with PBS, and centrifuged again in the same manner, repeating twice. Then, we resuspended the cells with $100 \mu \mathrm{L}$ of binding buffer after discarding the supernatant. After that, we added $5 \mu \mathrm{L}$ of Annexin V-FITc (KeyGen, 
TABLE 1: Real-time PCR primers.

\begin{tabular}{lrc}
\hline Gene name & Forward $\left(5^{\prime}>3^{\prime}\right)$ & Reverse $\left(5^{\prime}>3^{\prime}\right)$ \\
\hline Bax & CAGTTGAAGTTGCCATCAGC & CAGTTGAAGTTACCATCAGC \\
Bcl-2 & GACTGAGTACCTGAACCGGCATC & CTGAGCAGCGTCTTCAGAGACA \\
SOD 1 & GGTGAACCAGTTGTGTTGTC & CCGTCCTTTCCAGCAGTC \\
SOD2 & CAGACCTGCCTTACGACTATGG & CTCGGTGGCGTTGAGATTGTT \\
$\mathrm{IL}-1 \beta$ & GCAACTGTTCCTGAACTCAACT & ATCTTTTGGGGTCCGTCAACT \\
TNF- $\alpha$ & CCTCTCTCTAATCAGCCCTCTG & GAGGACCTGGGAGTAGATGAG \\
$\mathrm{I} \kappa \mathrm{K} \alpha$ & GTCAGGACCGTGTTCTCAAGG & GCTTCTTTGATGTTACTGAGGGC \\
$\mathrm{I} \kappa \mathrm{B}-\alpha$ & GGATCTAGCAGCTACGTACG & TTAGGACCTGACGTAACACG \\
p65 & ACTGCCGGGATGGCTACTAT & TCTGGATTCGCTGGCTAATGG \\
GAPDH & ACAACTTTGGTATCGTGGAAGG & GCCATCACGCCACAGTTTC \\
\hline
\end{tabular}

RT-PCR: quantitative reverse-transcription polymerase chain reaction.

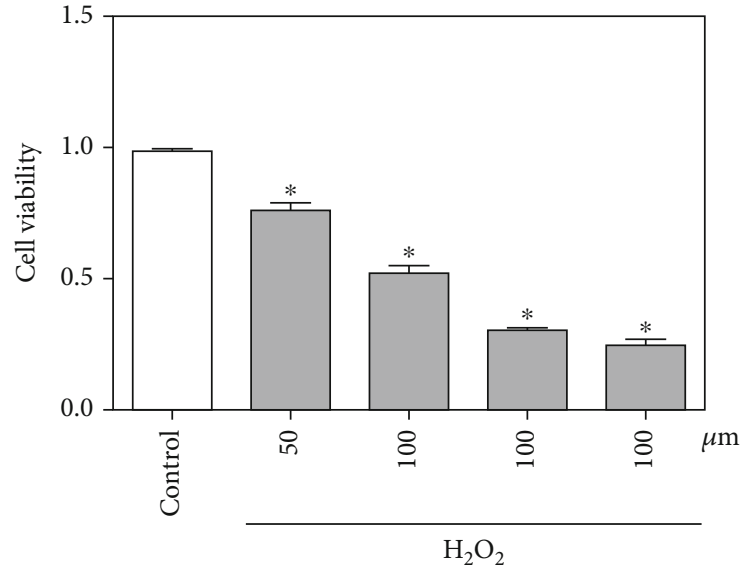

(a)

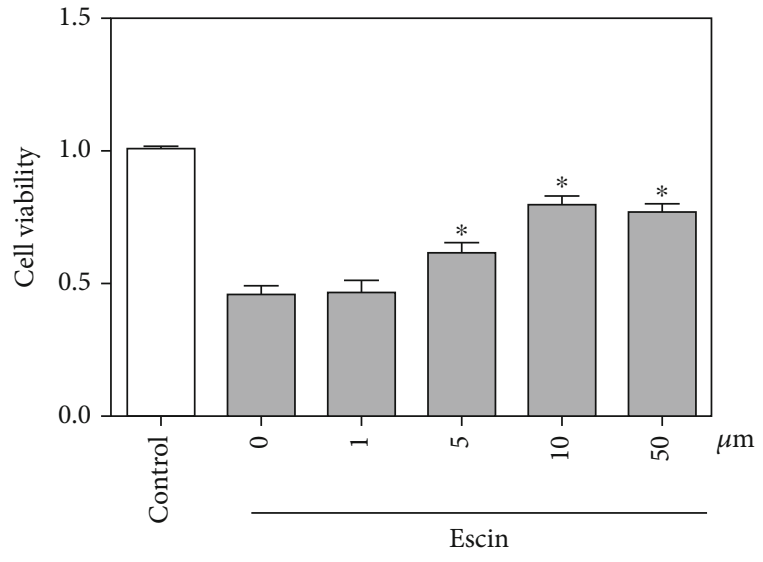

(b)

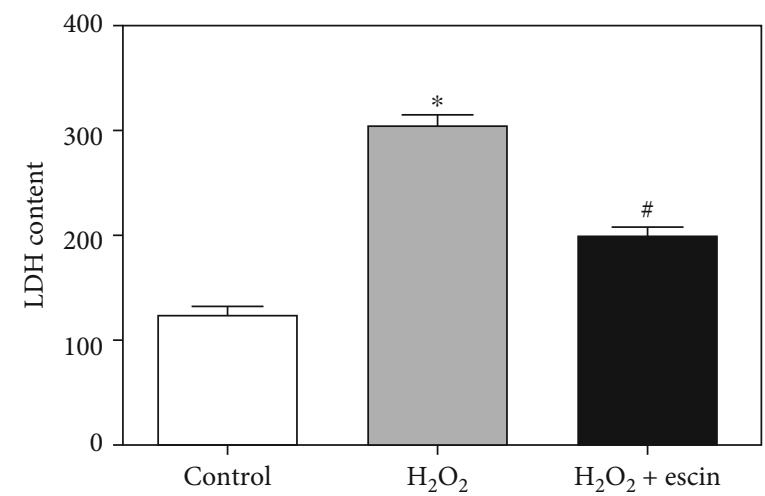

(c)

FIgURE 1: Escin protected $\mathrm{H} 9 \mathrm{c} 2$ cells from damage. (a) CCK-8 assay showed viability of $\mathrm{H} 9 \mathrm{c} 2$ cells at different concentrations of $\mathrm{H}_{2} \mathrm{O}_{2}$ ( ${ }^{*} p<0.05$ vs. control, $n=3$ ). (b) CCK-8 assay showed cell viability after addition of different concentrations of escin in $\mathrm{H}_{2} \mathrm{O}_{2}$-treated H9c2 cells $\left({ }^{*} p<0.05\right.$ vs. $0 \mu \mathrm{M}, n=3$ ). (c) The LDH content increased significantly in the $\mathrm{H}_{2} \mathrm{O}_{2}$ treatment group and decreased significantly in the $\mathrm{H}_{2} \mathrm{O}_{2}+$ escin group $\left({ }^{*} p<0.05\right.$ vs. control; ${ }^{*} p<0.05$ vs. $\left.\mathrm{H}_{2} \mathrm{O}_{2}, n=3\right)$.

Shanghai, China) and $5 \mu \mathrm{L}$ of propidium iodide (KeyGen, Shanghai, China) in per tube in the dark. Finally, the apoptotic H9c2 cells were detected using flow cytometry.

2.10. IL-1 Immunofluorescence. $\mathrm{H} 9 \mathrm{c} 2$ cells were placed in a 24 -well plate, fixed with $4 \%$ paraformaldehyde after the above treatment, then added goat serum, and incubated for 1 hour. After that, an appropriate amount of primary antibody IL- $1 \beta$ was added and incubated overnight at 4 degrees Celsius. On the second day, we added the corresponding fluorescent secondary antibody and incubated them in the dark for 1 hour. 4',6-Diamidino-2-phenylindole (DAPI) 

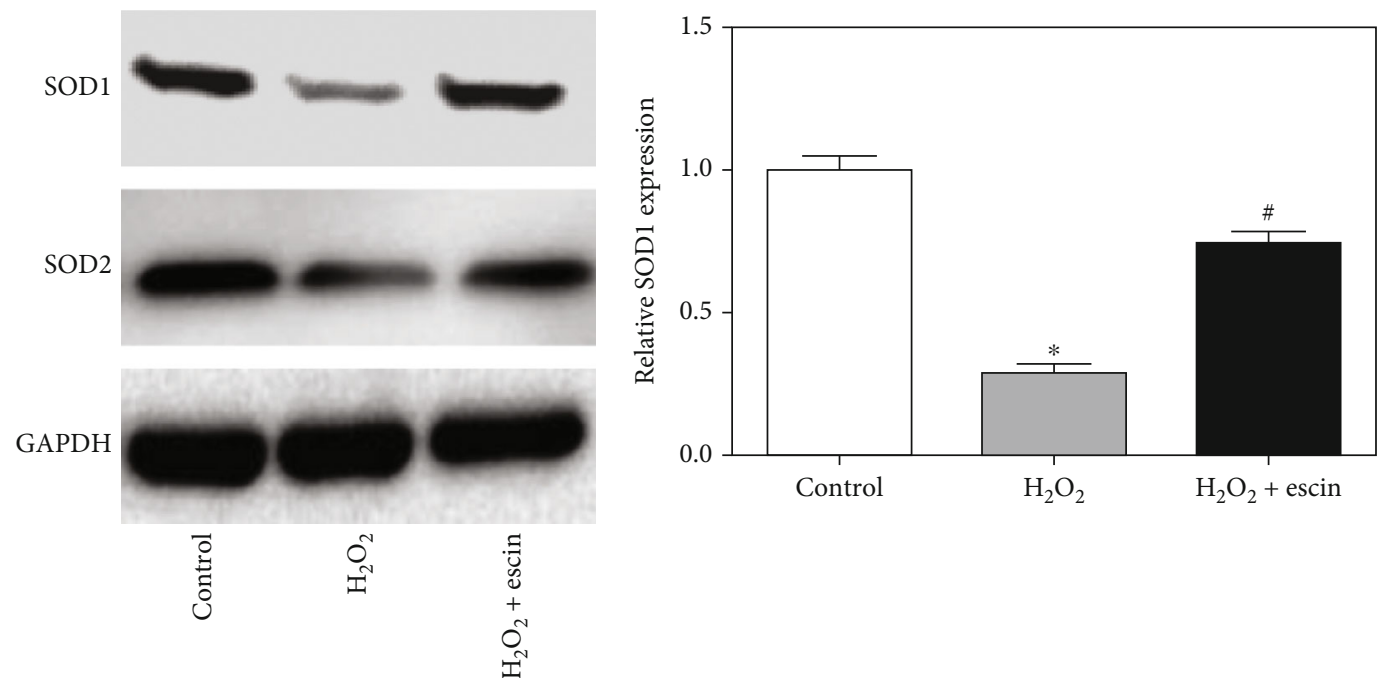

(a)

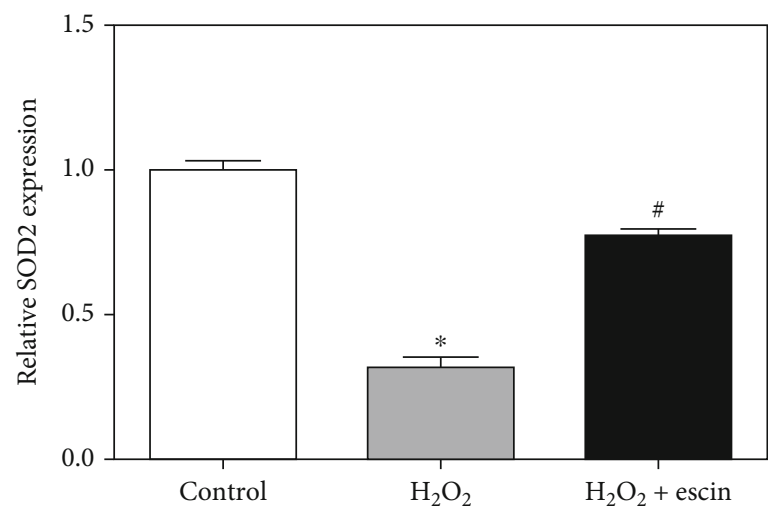

(c)

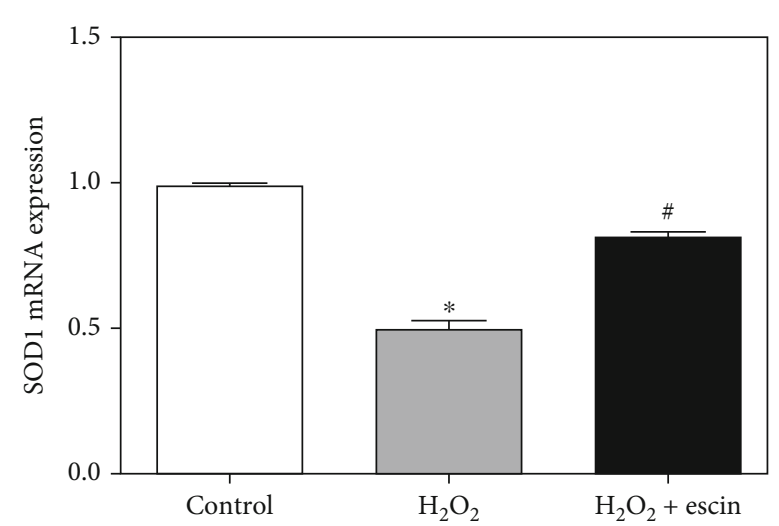

(d)

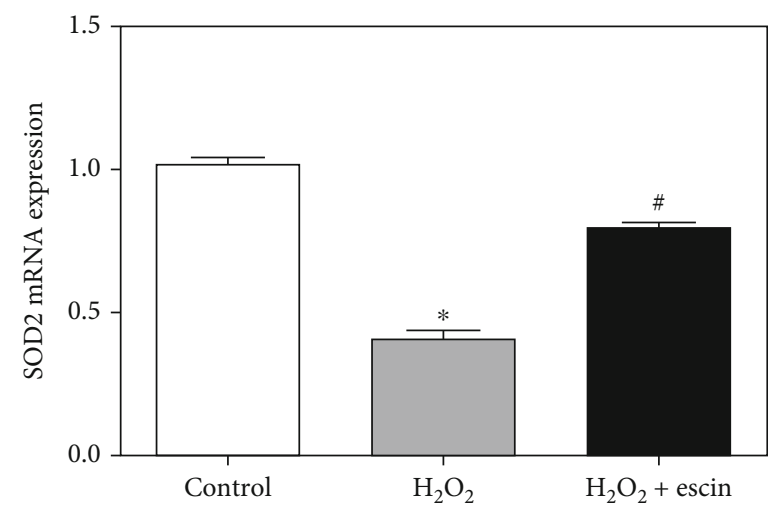

(e)

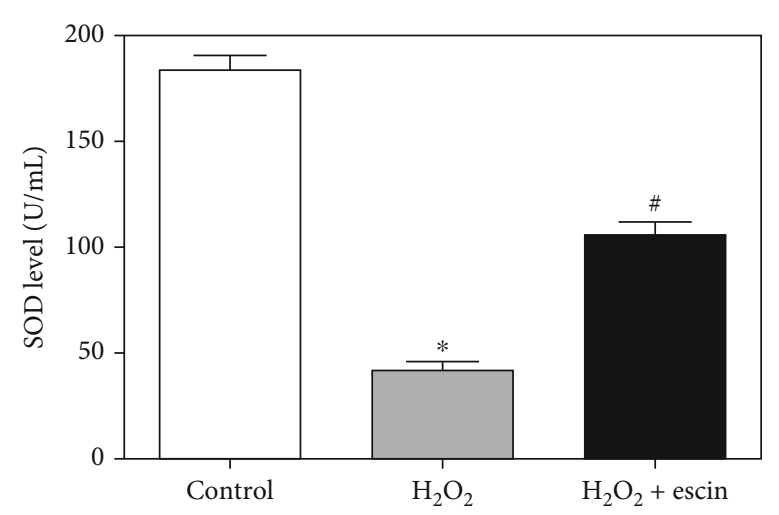

(f)

Figure 2: Continued. 


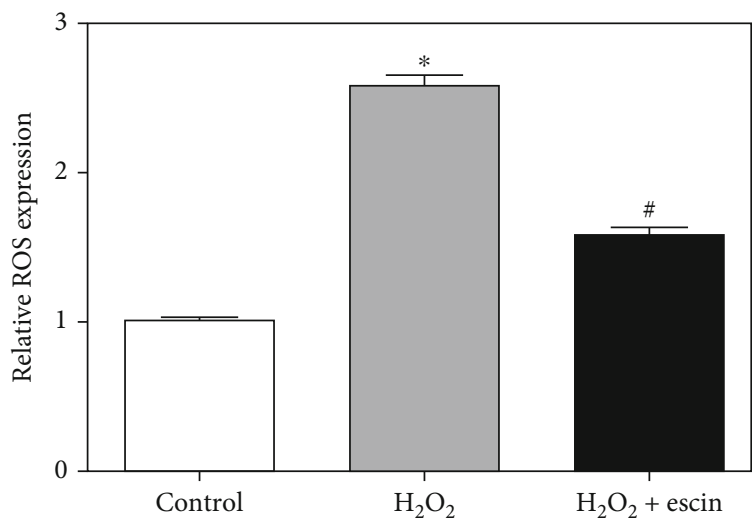

(g)

Figure 2: Escin inhibited oxidative stress in H9c2 cells. (a) The expression of SOD1 and SOD2 in the $\mathrm{H}_{2} \mathrm{O}_{2}$ treatment group decreased significantly, and the expression of SOD1 and SOD2 increased in the $\mathrm{H}_{2} \mathrm{O}_{2}$ escin group. (b) Statistical results of protein level of SOD1 $\left({ }^{*} p<0.05\right.$ vs. control; ${ }^{\#} p<0.05$ vs. $\left.\mathrm{H}_{2} \mathrm{O}_{2}, n=3\right)$. (c) Statistical results of protein level of SOD2 $\left({ }^{*} p<0.05\right.$ vs. control; ${ }^{\#} p<0.05$ vs. $\mathrm{H}_{2} \mathrm{O}_{2}$, $n=3$ ). (d) The expression of SOD1 mRNA in the $\mathrm{H}_{2} \mathrm{O}_{2}$ treatment group decreased significantly, and the expression increased in the $\mathrm{H}_{2} \mathrm{O}_{2}+$ escin group $\left({ }^{*} p<0.05\right.$ vs. control; ${ }^{*} p<0.05$ vs. $\mathrm{H}_{2} \mathrm{O}_{2}, n=3$ ). (e) The expression of SOD2 mRNA in the $\mathrm{H}_{2} \mathrm{O}_{2}$ treatment group decreased significantly, and the expression increased in the $\mathrm{H}_{2} \mathrm{O}_{2}+$ escin group $\left({ }^{*} p<0.05\right.$ vs. control; ${ }^{\#} p<0.05$ vs. $\left.\mathrm{H}_{2} \mathrm{O}_{2}, n=3\right)$. (f) SOD activity assay showed that $\mathrm{H}_{2} \mathrm{O}_{2}$ can significantly reduce SOD levels, while escin can reverse SOD levels $\left({ }^{*} p<0.05\right.$ vs. control; ${ }^{*} p<0.05$ vs. $\mathrm{H}_{2} \mathrm{O}_{2}, n=3$ ). (g) The expression of ROS increased in the $\mathrm{H}_{2} \mathrm{O}_{2}$ treatment group but decreased significantly in the $\mathrm{H}_{2} \mathrm{O}_{2}+\mathrm{escin}$ group $\left({ }^{*} p<0.05\right.$ vs. control; ${ }^{*} p<0.05$ vs. $\left.\mathrm{H}_{2} \mathrm{O}_{2}, n=3\right)$.

was also added to stain the nucleus. Finally, it was observed by a Confocal Laser Scanning Microscope (CLSM).

2.11. Statistics Analysis. Measurement data is expressed as $\chi \pm s$. Differences between two groups were analyzed by using the Student $t$-test. Comparison between multiple groups was done using one-way ANOVA test followed by post hoc test (Least Significant Difference). Least Significant Difference (LSD) test or Student-Newman-Keuls (SNK) test was used for pairwise comparison under the condition of homogeneity of variance. Test level $\alpha=0.05$. All experiments were repeated 3 times.

\section{Results}

3.1. Escin Protected $\mathrm{H}_{2} \mathrm{O}_{2}$-Induced H9c2 Cell Injury. To measure the appropriate $\mathrm{H}_{2} \mathrm{O}_{2}$ concentration for $\mathrm{H} 9 \mathrm{c} 2$ cells, $\mathrm{H} 9 \mathrm{c} 2$ cells were treated with different concentrations of $\mathrm{H}_{2} \mathrm{O}_{2}$ for 4 hours. As shown in Figure 1(a), when H9c2 cells were treated with $100 \mu \mathrm{M}$ of $\mathrm{H}_{2} \mathrm{O}_{2}$, cell viability was suppressed by about $50 \%$ by CCK- 8 assay, so we selected $100 \mu \mathrm{M}$ of $\mathrm{H}_{2} \mathrm{O}_{2}$ for subsequent studies. Next, in order to determine the optimal dosing concentration, we treated $\mathrm{H}_{2} \mathrm{O}_{2}$-treated $\mathrm{H} 9 \mathrm{c} 2$ cells with different concentrations of escin for 24 hours. We measured cell viability using CCK-8 assay, and the highest cell viability was obtained when H9c2 cells were treated with $10 \mu \mathrm{M}$ of escin (Figure 1(b)). After that, we collected the supernatant of H9c2 cells and detected them with the $\mathrm{LDH}$ kit. The results showed that escin significantly inhibited $\mathrm{H}_{2} \mathrm{O}_{2}$-mediated $\mathrm{LDH}$ elevation (Figure 1(c)). These results indicated that escin can act directly on $\mathrm{H} 9 \mathrm{c} 2$ cells and reduced the damage caused by $\mathrm{H}_{2} \mathrm{O}_{2}$.
3.2. Escin Inhibited $\mathrm{H}_{2} \mathrm{O}_{2}$-Induced Oxidative Stress in $\mathrm{H} 9 \mathrm{c} 2$ Cells. We used Western blot to detect the expression levels of SOD1 protein and SOD2 protein (Figure 2(a)). In the $\mathrm{H}_{2} \mathrm{O}_{2}$ treatment group, the expression levels of SOD1 and SOD2 were greatly decreased compared to the control group, while the treatment with escin greatly increased the expression levels of SOD1 and SOD2 (Figures 2(b) and 2(c)). Then, we used real-time PCR to detect the expression levels of SOD1 mRNA and SOD2 mRNA, which were consistent with the results of Western blot (Figures 2(d) and $2(\mathrm{e}))$. At the same time, the SOD activity assay was used to detect the level of SOD. The results showed that the addition of escin can significantly reverse the decrease of $\mathrm{H}_{2} \mathrm{O}_{2}$-mediated SOD levels (Figure 2(f)). Finally, we tested the level of ROS production by DHR dye assay. We can see from Figure $2(\mathrm{~g})$ that the treatment of $\mathrm{H}_{2} \mathrm{O}_{2}$ increased the level of ROS production, while in the $\mathrm{H}_{2} \mathrm{O}_{2}+$ escin group, the level of ROS production decreased significantly. These results demonstrated that escin can inhibit oxidative stress in $\mathrm{H} 9 \mathrm{c} 2$ cells treated with $\mathrm{H}_{2} \mathrm{O}_{2}$.

3.3. Escin Inhibited $\mathrm{H}_{2} \mathrm{O}_{2}$-Induced Apoptosis in $\mathrm{H} 9 \mathrm{c} 2$ Cells. First, we examined the expression of $\mathrm{Bcl}-2$ and Bax proteins by Western blot (Figure 3(a)). It can be seen that the expression of $\mathrm{Bcl}-2$ in the $\mathrm{H}_{2} \mathrm{O}_{2}$ treatment group was greatly decreased compared with the control group, while the level of Bax was greatly increased. After using escin, the level of Bcl-2 was increased and the level of Bax was decreased (Figures 3(b) and 3(c)). Similarly, we detected the levels of Bcl-2 and Bax mRNA using real-time PCR, which was consistent with the results of Western blot (Figures 3(d) and $3(\mathrm{e}))$. To further demonstrate the antiapoptotic effect of escin, we used TUNEL staining to detect the level of TUNEL-positive cells. It can be seen that the TUNEL- 


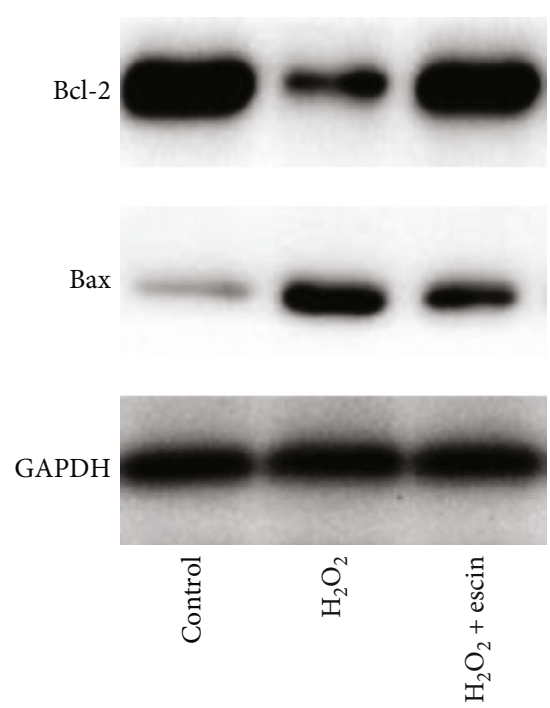

(a)

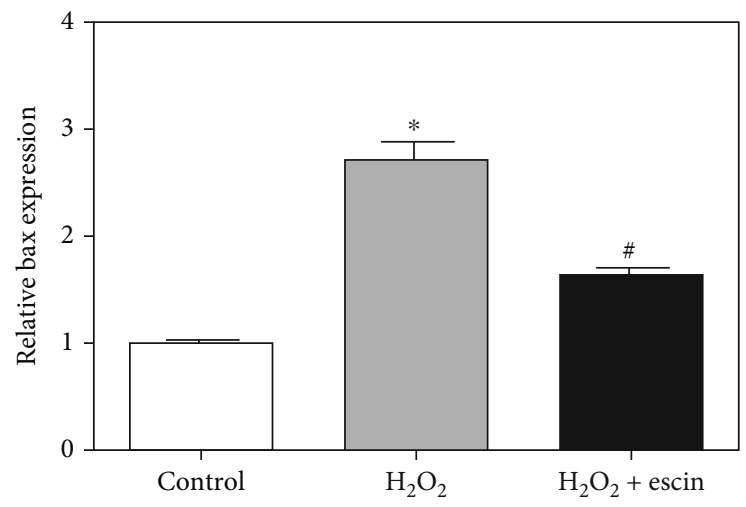

(c)

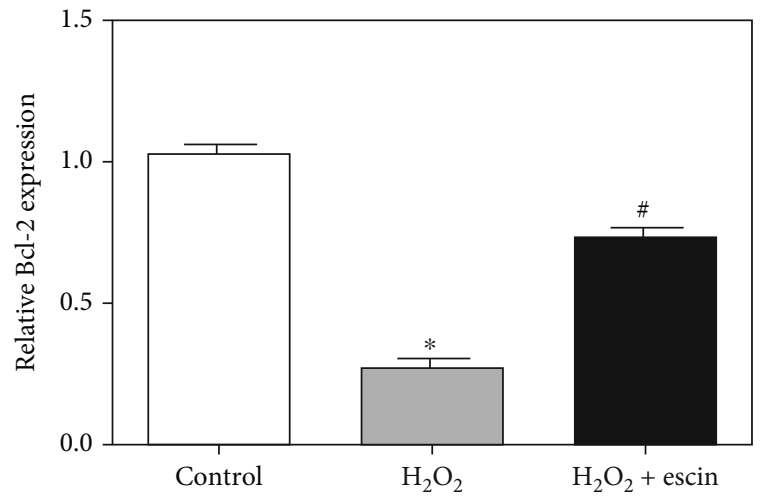

(b)

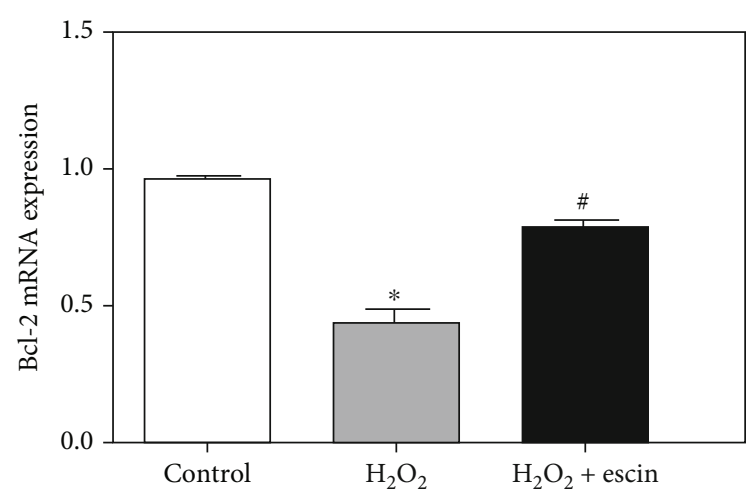

(d)

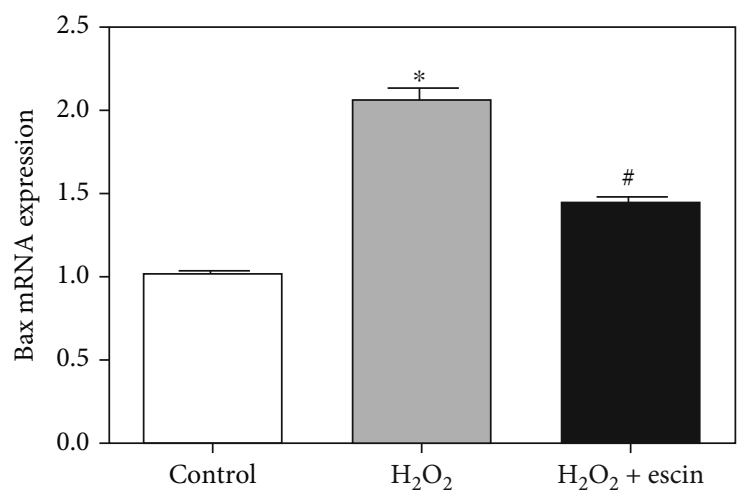

(e)

Figure 3: Continued. 

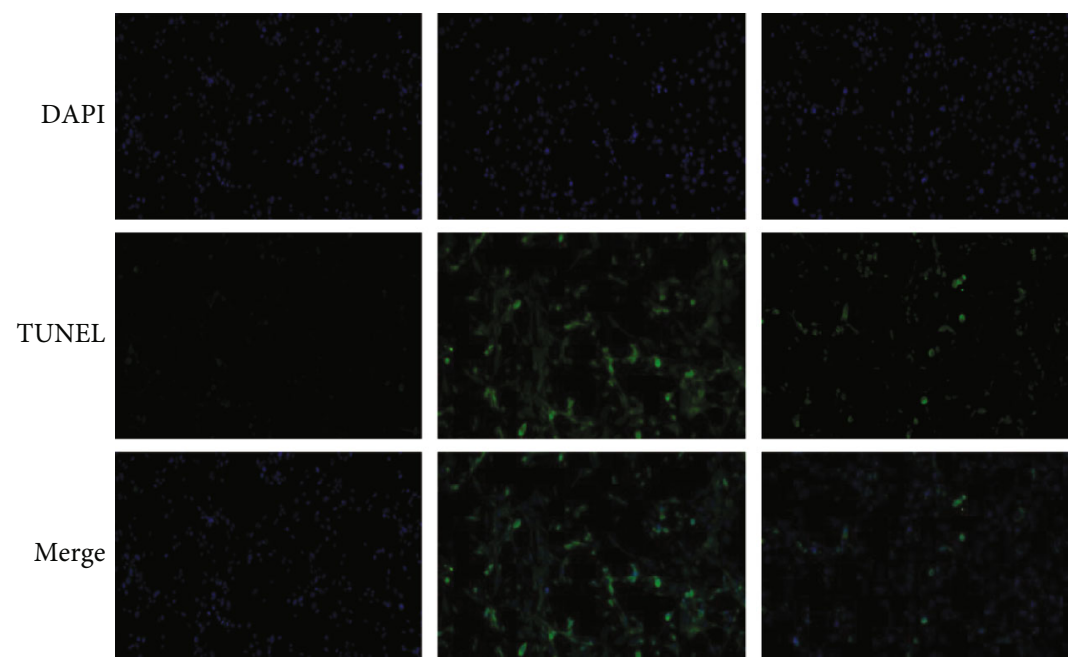

Control

$\mathrm{H}_{2} \mathrm{O}_{2}$

$\mathrm{H}_{2} \mathrm{O}_{2}+$ escin

(f)
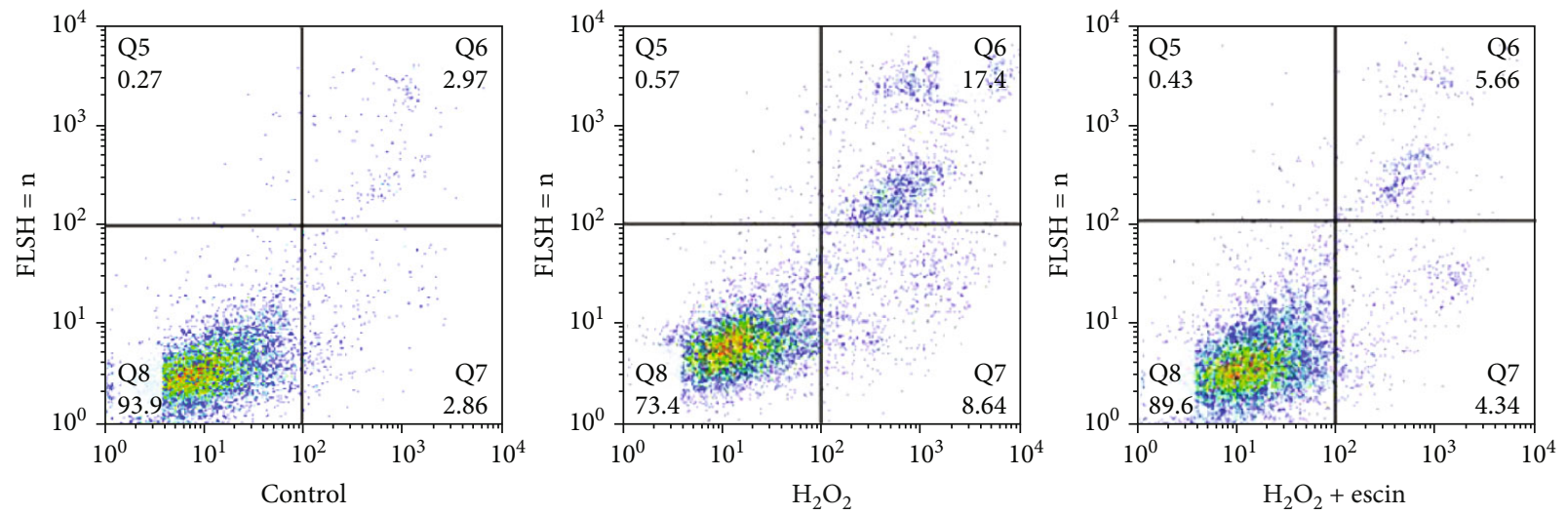

$(\mathrm{g})$

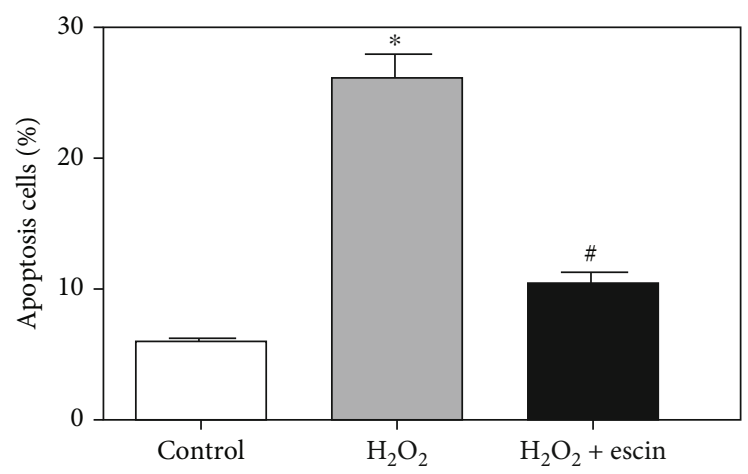

(h)

FIGURE 3: Escin inhibited apoptosis of H9c2 cells. (a) The expression of Bcl-2 in the $\mathrm{H}_{2} \mathrm{O}_{2}$ treatment group decreased significantly but increased in the $\mathrm{H}_{2} \mathrm{O}_{2}+$ escin group. Bax expression was opposite to Bcl-2. (b) Statistical results of protein level of $\mathrm{Bcl}-2\left({ }^{*} p<0.05\right.$ vs. control; ${ }^{\#} p<0.05$ vs. $\mathrm{H}_{2} \mathrm{O}_{2}, n=3$ ). (c) Statistical results of expression of Bax ( ${ }^{*} p<0.05$ vs. control; ${ }^{\#} p<0.05$ vs. $\mathrm{H}_{2} \mathrm{O}_{2}, n=3$ ). (d) The expression of Bcl-2 mRNA was consistent with the Bcl-2 protein $\left({ }^{*} p<0.05\right.$ vs. control; ${ }^{*} p<0.05$ vs. $\left.\mathrm{H}_{2} \mathrm{O}_{2}, n=3\right)$. (e) The expression of Bax mRNA was consistent with the Bax protein $\left({ }^{*} p<0.05\right.$ vs. control; ${ }^{*} p<0.05$ vs. $\left.\mathrm{H}_{2} \mathrm{O}_{2}, n=3\right)$. (f) TUNEL staining showed that escin can obviously reduce the increase of $\mathrm{H} 9 \mathrm{c} 2$ cell apoptosis caused by $\mathrm{H}_{2} \mathrm{O}_{2}$ (magnification: $\left.\times 400\right)$. $(\mathrm{g})$ The apoptotic rate of the $\mathrm{H}_{2} \mathrm{O}_{2}$ treatment group increased and decreased in the $\mathrm{H}_{2} \mathrm{O}_{2}+$ escin group. (h) Statistical results of apoptotic rate of $\mathrm{H} 9 \mathrm{c} 2$ cells $\left({ }^{*} p<0.05\right.$ vs. control; ${ }^{*} p<0.05$ vs. $\mathrm{H}_{2} \mathrm{O}_{2}, n=3$ ). 


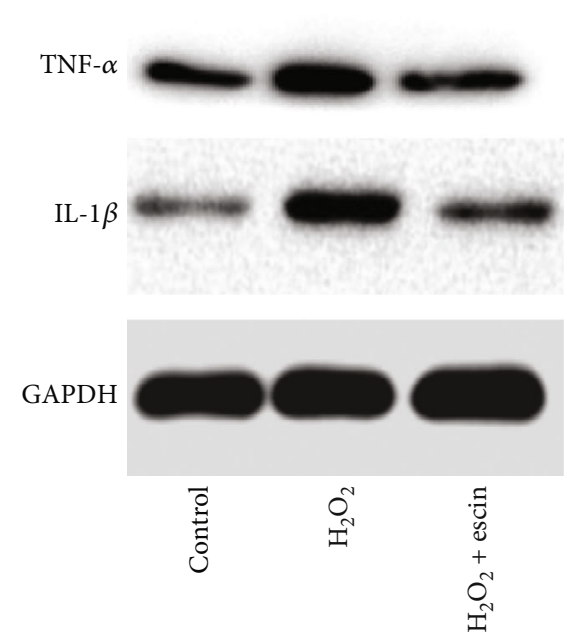

(a)

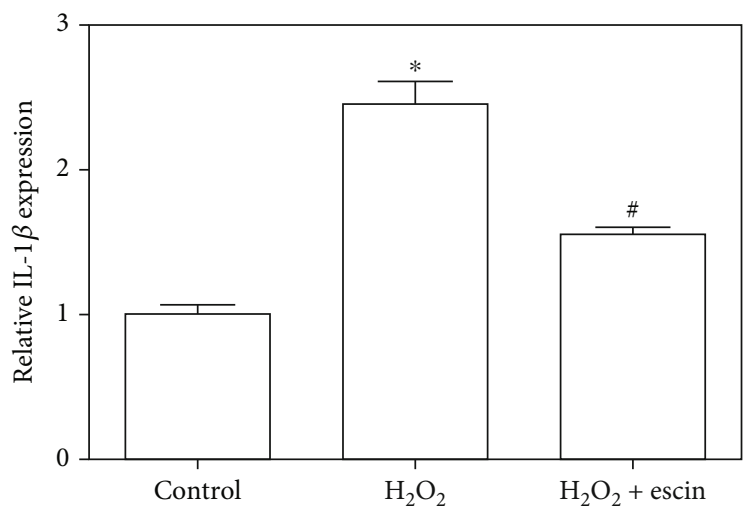

(c)

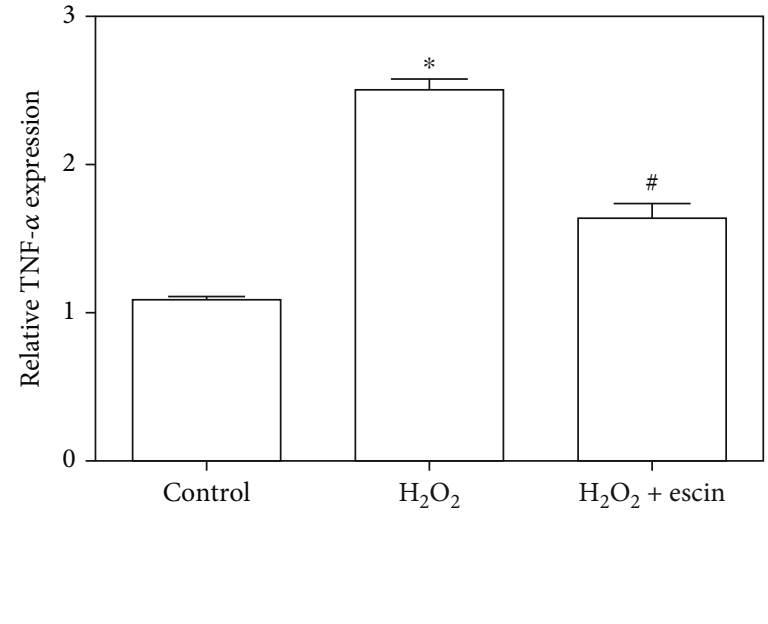

(b)

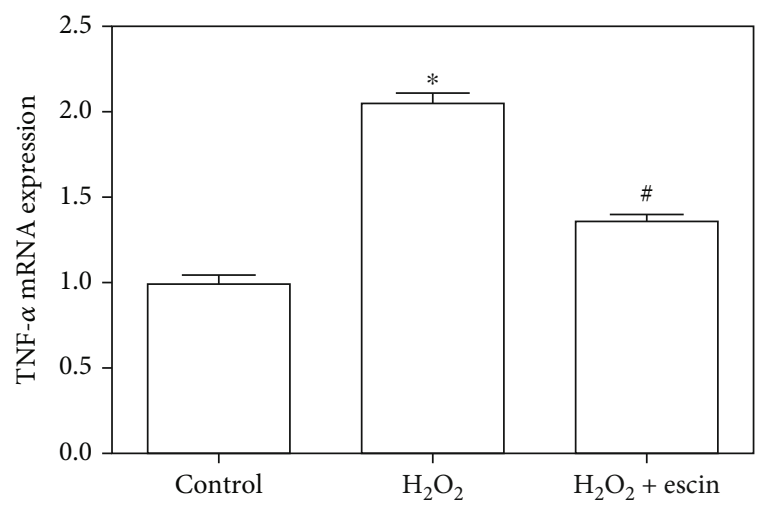

(d)

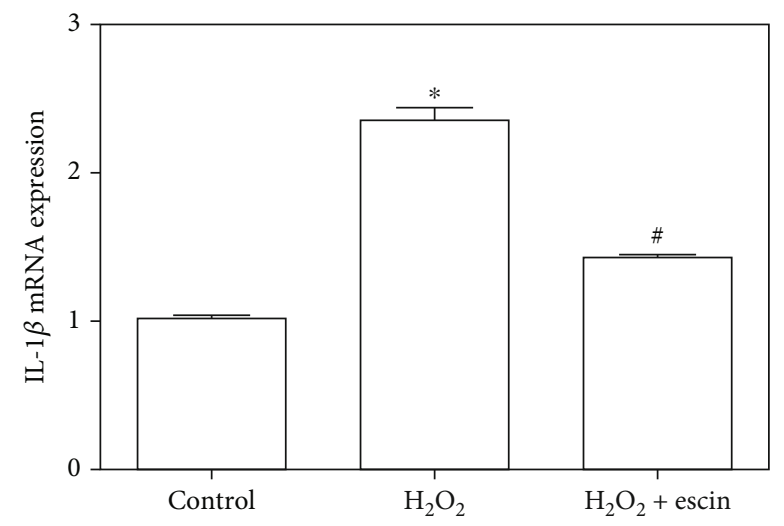

(e)

FIgUre 4: Continued. 

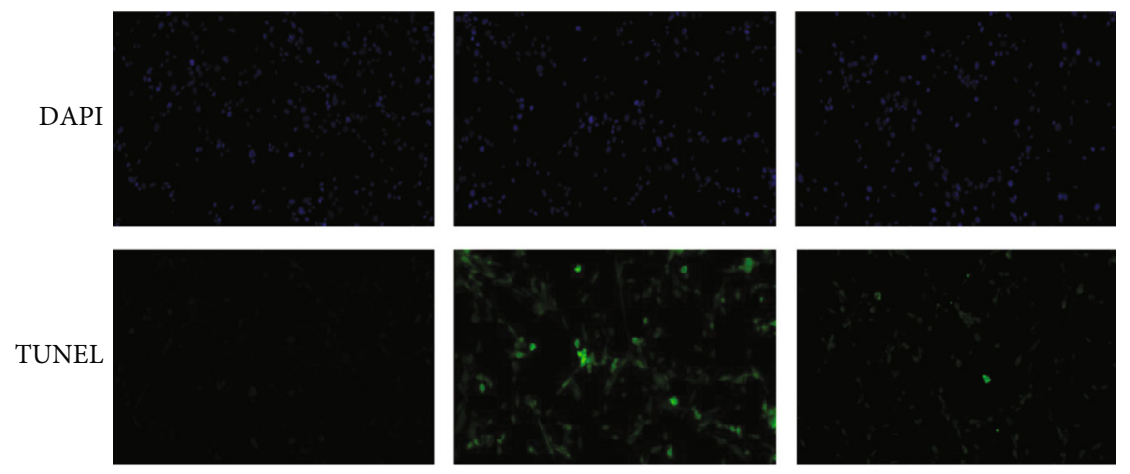

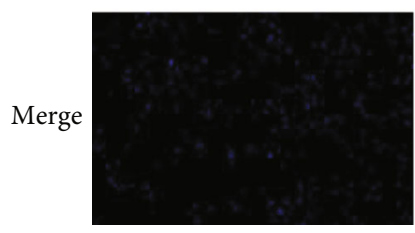

Control

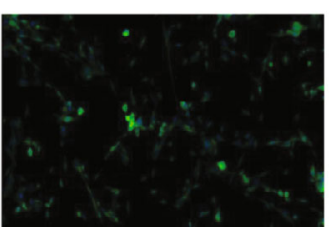

$\mathrm{H}_{2} \mathrm{O}_{2}$

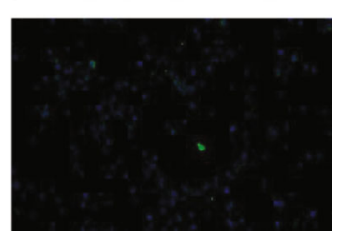

$\mathrm{H}_{2} \mathrm{O}_{2}+$ escin

(f)

Figure 4: Escin inhibited inflammation of $\mathrm{H} 9 \mathrm{c} 2$ cells. (a) The expression of IL-1 $\beta$ and TNF- $\alpha$ in the $\mathrm{H}_{2} \mathrm{O}_{2}$ treatment group increased significantly but decreased in the $\mathrm{H}_{2} \mathrm{O}_{2}$ +escin group. (b) Statistical results of expression of TNF- $\alpha\left({ }^{*} p<0.05\right.$ vs. control; ${ }^{*} p<0.05$ vs. $\left.\mathrm{H}_{2} \mathrm{O}_{2}, n=3\right)$. (c) Statistical results of expression of IL- $1 \beta$ ( ${ }^{*} p<0.05$ vs. control; ${ }^{*} p<0.05$ vs. $\mathrm{H}_{2} \mathrm{O}_{2}, n=3$ ). (d) TNF- $\alpha$ mRNA expression was similar to the results of Western blot $\left({ }^{*} p<0.05\right.$ vs. control; ${ }^{\#} p<0.05$ vs. $\left.\mathrm{H}_{2} \mathrm{O}_{2}, n=3\right)$. (e) IL- $1 \beta$ mRNA expression was also similar to the results of Western blot $\left({ }^{*} p<0.05\right.$ vs. control; ${ }^{*} p<0.05$ vs. $\mathrm{H}_{2} \mathrm{O}_{2}, n=3$ ). (f) Immunofluorescence showed that escin significantly reduced $\mathrm{H}_{2} \mathrm{O}_{2}$-mediated elevation of IL- $1 \beta$ (magnification: $\times 400$ ).

positive cells in the $\mathrm{H}_{2} \mathrm{O}_{2}+$ escin group were greatly reduced compared to the $\mathrm{H}_{2} \mathrm{O}_{2}$ treatment group (Figure 3(f)). We also used flow cytometry to detect the effect of escin on $\mathrm{H} 9 \mathrm{c} 2$ cells treated with $\mathrm{H}_{2} \mathrm{O}_{2}$. We can see that escin can significantly reduce the apoptotic rate of $\mathrm{H}_{2} \mathrm{O}_{2}$-treated $\mathrm{H} 9 \mathrm{c} 2$ cells (Figures $3(\mathrm{~g})$ and $3(\mathrm{~h})$ ). These results indicated that escin can inhibit $\mathrm{H}_{2} \mathrm{O}_{2}$-mediated apoptosis of $\mathrm{H} 9 \mathrm{c} 2$ cells.

\subsection{Escin Inhibited $\mathrm{H}_{2} \mathrm{O}_{2}$-Induced Inflammation of $\mathrm{H} 9 \mathrm{c} 2$} Cells. The expression of IL- $1 \beta$ and TNF- $\alpha$ was examined by Western blotting (Figure 4(a)). We can see that $\mathrm{H}_{2} \mathrm{O}_{2}$ significantly induced the increase of IL- $1 \beta$ and TNF- $\alpha$, while the escin inhibited their increase (Figures $4(\mathrm{~b})$ and $4(\mathrm{c})$ ). Similar results were obtained for mRNA levels (Figures 4(d) and 4(e)). Immunofluorescence showed that IL- $1 \beta$ expression in the $\mathrm{H}_{2} \mathrm{O}_{2}$ +escin group was significantly decreased compared with the $\mathrm{H}_{2} \mathrm{O}_{2}$ treatment group (Figure 4(f)). These results showed that escin can inhibit the inflammation of $\mathrm{H} 9 \mathrm{c} 2$ cells induced by $\mathrm{H}_{2} \mathrm{O}_{2}$.

3.5. Escin Inhibited the NF- $\kappa B$ Pathway. The NF- $\kappa$ B pathway plays a very important role in regulating apoptosis and oxidative stress, so we examined the NF- $\kappa \mathrm{B}$ pathway in different treatment groups by Western blot (Figure 5(a)). We can see from Figures 5(b)-5(d) that the expression of p65 and $\mathrm{I} \kappa \mathrm{B}$ kinase $\alpha(\mathrm{I} \kappa \mathrm{K} \alpha)$ in the $\mathrm{H}_{2} \mathrm{O}_{2}$ treatment group was significantly increased, while the expression of inflammatory inhibitor NF- $\kappa \mathrm{B} \alpha \quad(\mathrm{I} \kappa \mathrm{B}-\alpha)$ was greatly decreased, compared with the control group. After treatment with escin, the expression of p65 and $\mathrm{I} \kappa \mathrm{K} \alpha$ was decreased, while the expression level of $\mathrm{I} \kappa \mathrm{B}-\alpha$ increased compared to the $\mathrm{H}_{2} \mathrm{O}_{2}$ treatment group. And the results of the real-time PCR matched the results of the Western blot (Figures $5(\mathrm{e})-5(\mathrm{~g})$ ). These results suggested that escin can inhibit the NF- $\kappa$ B pathway.

\section{Discussion}

In this present study, we revealed for the first time the role of escin in MI. $\mathrm{H}_{2} \mathrm{O}_{2}$ treatment successfully induced oxidative stress, inflammation, and apoptosis of $\mathrm{H} 9 \mathrm{c} 2$ cardiomyocytes. However, escin can reverse the damage of $\mathrm{H} 9 \mathrm{c} 2$ cells caused by $\mathrm{H}_{2} \mathrm{O}_{2}$. This protective effect was achieved at least in part by targeting the NF- $\kappa \mathrm{B}$ pathway.

AMI is a serious health problem in the world with a high mortality rate [9]. Current treatments can reconstitute the blood supply to the ischemic areas [10]. However, these treatments do not fully restore the apoptosis and oxidative stress of some cardiomyocytes. Previous studies have shown that in AMI, the myocardial ischemia site produces a large amount of ROS due to oxidative stress, which causes damage to the myocardial cell membrane, and at the same time produces a large number of inflammatory factors, causing apoptosis of cardiomyocytes [11]. Therefore, in addition to rebuilding the blood supply in the ischemic areas, treatments such as antioxidative stress, antiapoptosis, and anti-inflammatory are also essential.

Many studies have previously reported antioxidative, antiapoptotic, and anti-inflammatory effects of escin in other diseases. So, we want to verify whether escin has a similar effect in MI. We first tested the cell viability of 


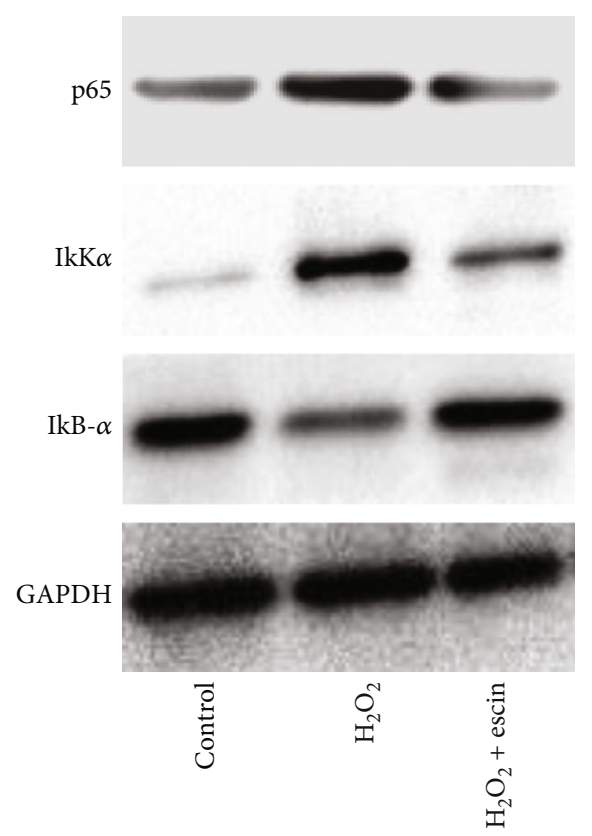

(a)

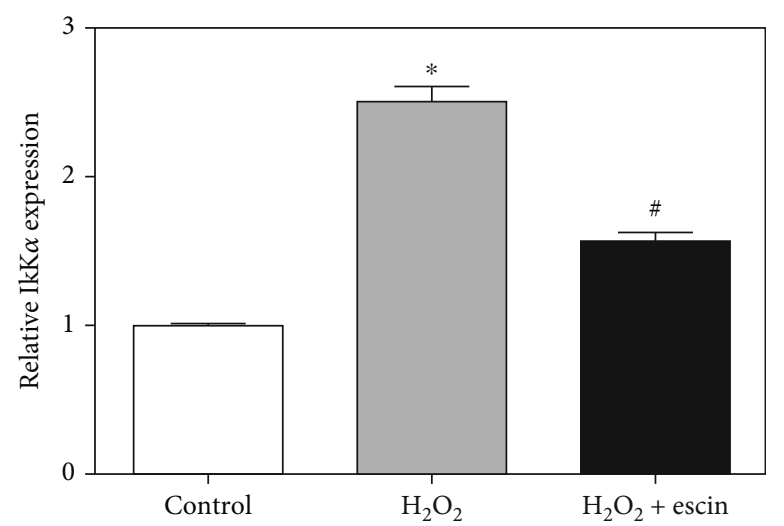

(c)

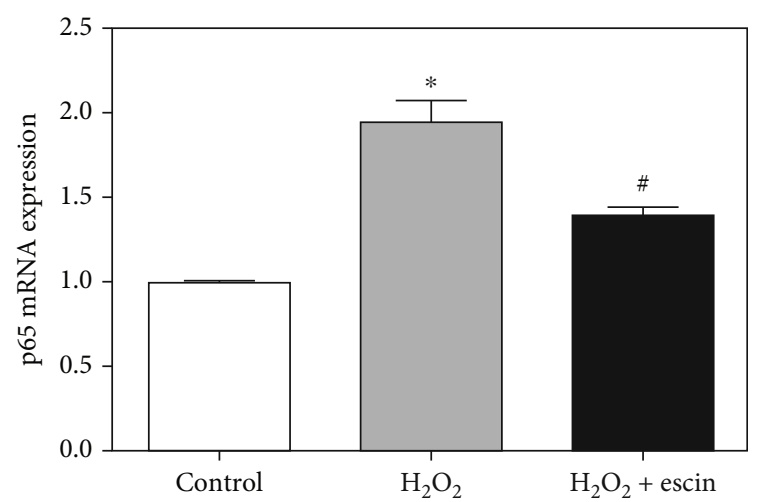

(e)

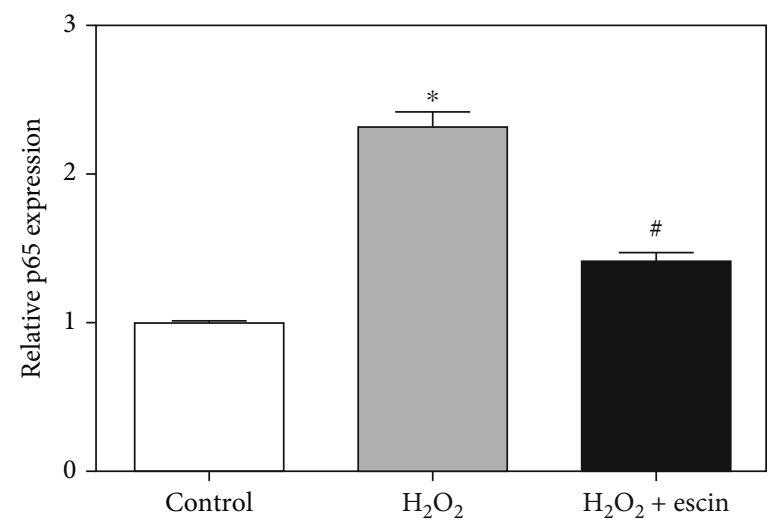

(b)

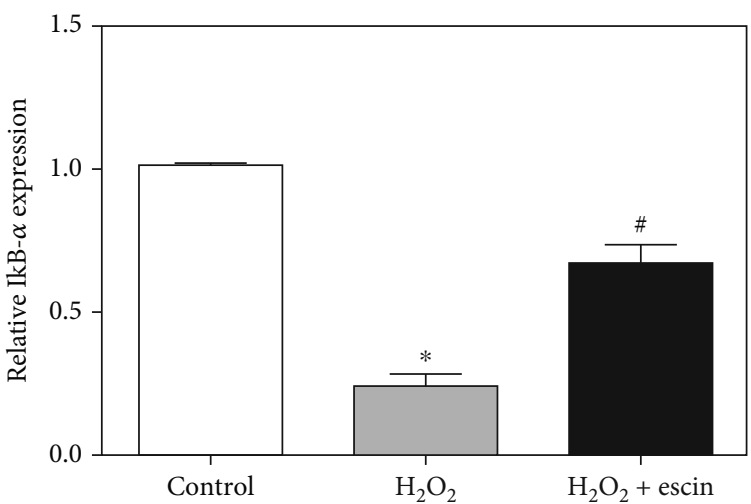

(d)

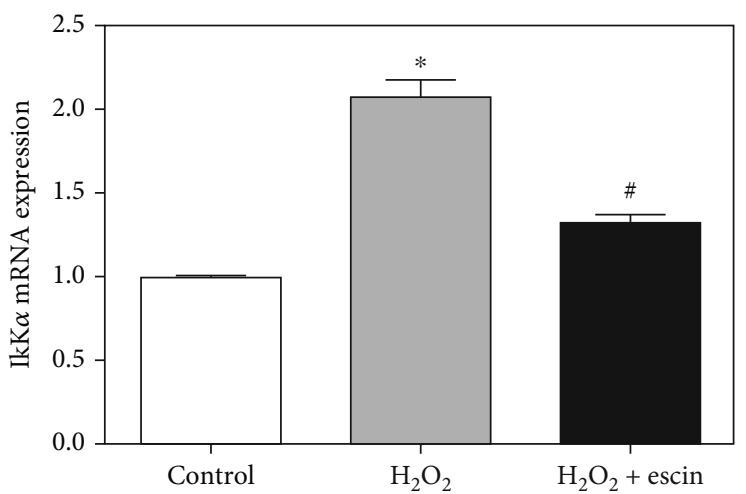

(f)

Figure 5: Continued. 


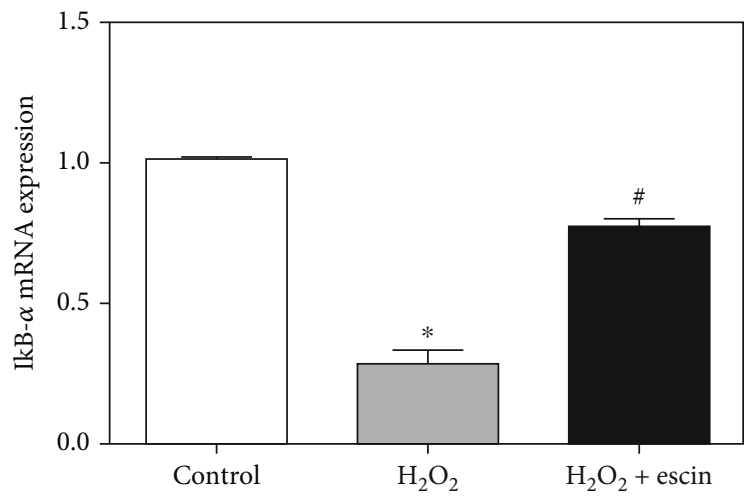

(g)

FIgURE 5: Escin inhibited the NF- $\kappa$ B pathway. (a) In the $\mathrm{H}_{2} \mathrm{O}_{2}$ treatment group, the expression of p65 and I $\kappa \mathrm{K} \alpha$ increased, and the expression of $\mathrm{I} \kappa \mathrm{B}-\alpha$ decreased. In the $\mathrm{H}_{2} \mathrm{O}_{2}$ +escin group, the expression of $\mathrm{p} 65$ and $\mathrm{I} \kappa \mathrm{K} \alpha$ decreased, and the expression of $\mathrm{I} \kappa \mathrm{B}-\alpha$ increased. (b) Statistical results of protein level of $\mathrm{p} 65\left({ }^{*} p<0.05\right.$ vs. control; ${ }^{*} p<0.05$ vs. $\left.\mathrm{H}_{2} \mathrm{O}_{2}, n=3\right)$. (c) Statistical results of protein level of $\mathrm{I} \kappa \mathrm{K} \alpha\left({ }^{*} p<0.05\right.$ vs. control; ${ }^{*} p<0.05$ vs. $\left.\mathrm{H}_{2} \mathrm{O}_{2}, n=3\right)$. (d) Statistical results of protein level of I $\kappa \mathrm{B}-\alpha\left({ }^{*} p<0.05\right.$ vs. control; ${ }^{\#} p<0.05$ vs. $\mathrm{H}_{2} \mathrm{O}_{2}, n=3$ ). (e) Expression of p65 mRNA in three groups ( ${ }^{*} p<0.05$ vs. control; ${ }^{\#} p<0.05$ vs. $\mathrm{H}_{2} \mathrm{O}_{2}, n=3$ ). (f) Expression of $\mathrm{I} \kappa \mathrm{K} \alpha$ mRNA in three groups ( ${ }^{*} p<0.05$ vs. control; ${ }^{*} p<0.05$ vs. $\left.\mathrm{H}_{2} \mathrm{O}_{2}, n=3\right)$. (g) Expression of $\mathrm{I} \kappa \mathrm{B}-\alpha$ mRNA was consistent with the results of Western blot $\left({ }^{*} p<0.05\right.$ vs. control; ${ }^{*} p<0.05$ vs. $\left.\mathrm{H}_{2} \mathrm{O}_{2}, n=3\right)$.

H9c2 cells treated with $\mathrm{H}_{2} \mathrm{O}_{2}$ and found that escin did increase the cell viability. Then, we examined the expression of oxidative stress-related proteins, apoptosis-related proteins, and some inflammatory factors and also detected the corresponding mRNA expression. The final result confirmed our hypothesis that escin can inhibit oxidative stress, apoptosis, and inflammation in $\mathrm{H} 9 \mathrm{c} 2$ cells, thereby increasing cell viability. This also provided a potential treatment for MI.

Studies have shown that MI involves multiple signaling pathways such as Rho/ROCK pathway, MAPK pathway, and NF- $\kappa \mathrm{B}$ pathway [12]. Among them, NF- $\kappa \mathrm{B}$ pathway is a classical signaling pathway that has an important influence on inflammation, apoptosis, and oxidative stress. Xiong et al. [13] believed that quercetin acts to treat periodontitis through NF- $\kappa \mathrm{B}$ signaling pathway. Yi et al. [14] suggested that inhibition of $\mathrm{NF}-\kappa \mathrm{B}$ signaling pathway promoted autophagy and inhibited apoptosis and inflammation in nucleus pulposus cells. By detecting the expression of p65, $\mathrm{I} \kappa \mathrm{K} \alpha, \mathrm{I} \kappa \mathrm{B}-\alpha$ protein, and mRNA in different treatment groups, our study also confirmed that escin can inhibit cardiomyocyte apoptosis, inflammation, and oxidative stress through the NF- $\kappa \mathrm{B}$ pathway.

In summary, our study suggests that the effect of escin on $\mathrm{MI}$ is primarily due to the inhibition of the NF- $\kappa \mathrm{B}$ signaling pathway. This finding is of great help to the clinical treatment of MI.

\section{Conclusions}

Escin inhibits the NF- $\kappa \mathrm{B}$ pathway and thus inhibits oxidative stress, apoptosis, and inflammation induced by $\mathrm{H}_{2} \mathrm{O}_{2}$ in $\mathrm{H} 9 \mathrm{c} 2$ cells. Therefore, escin may provide a new treatment for MI.

\section{Data Availability}

The datasets used and analyzed during the current study are available from the corresponding author on reasonable request.

\section{Conflicts of Interest}

The authors declared no conflict of interest.

\section{References}

[1] K. Thygesen, J. S. Alpert, A. S. Jaffe, M. L. Simoons, B. R. Chaitman, and H. D. White, "Third Universal Definition of Myocardial Infarction," Global Heart, vol. 7, no. 4, pp. 275-295, 2012.

[2] M. Chiong, Z. V. Wang, Z. Pedrozo et al., "Cardiomyocyte death: mechanisms and translational implications," Cell Death \& Disease, vol. 2, no. 12, 2011.

[3] E. G. Nabel and E. Braunwald, "A Tale of Coronary Artery Disease and Myocardial Infarction," The New England Journal of Medicine, vol. 366, no. 1, pp. 54-63, 2012.

[4] D. Cheong, F. Arfuso, G. Sethi et al., "Molecular targets and anti-cancer potential of escin," Cancer Letters, vol. 422, pp. 1-8, 2018.

[5] G. P. Selvakumar, T. Manivasagam, K. R. Rekha, R. L. Jayaraj, and N. Elangovan, "Escin, a novel triterpene, mitigates chronic MPTP/p-induced dopaminergic toxicity by attenuating mitochondrial dysfunction, oxidative stress, and apoptosis," Journal of Molecular Neuroscience, vol. 55, no. 1, pp. 184-197, 2015.

[6] K. Wang, Y. Jiang, W. Wang, J. Ma, and M. Chen, "Escin activates AKT-Nrf2 signaling to protect retinal pigment epithelium cells from oxidative stress," Biochemical and Biophysical Research Communications, vol. 468, no. 4, pp. 541-547, 2015.

[7] C. L. Cheng, W. T. Chao, Y. H. Li et al., "Escin induces apoptosis in human bladder cancer cells: An in vitro and in vivo study," European Journal of Pharmacology, vol. 840, pp. 79$88,2018$. 
[8] D. L. Dong, C. Chen, R. Huo et al., "Reciprocal repression between microRNA-133 and calcineurin regulates cardiac hypertrophy," Hypertension, vol. 55, no. 4, pp. 946-952, 2010.

[9] J. Pöss, J. Köster, G. Fuernau et al., "Risk stratification for patients in cardiogenic shock after acute myocardial infarction," Journal of the American College of Cardiology, vol. 69, no. 15, pp. 1913-1920, 2017.

[10] M. Myojo, J. Ando, M. Uehara, M. Daimon, M. Watanabe, and I. Komuro, "Feasibility of extracorporeal shock wave myocardial revascularization therapy for post-acute myocardial infarction patients and refractory angina pectoris patients," International Heart Journal, vol. 58, no. 2, pp. 185-190, 2017.

[11] M. Neri, V. Fineschi, M. Di Paolo et al., "Cardiac oxidative stress and inflammatory cytokines response after myocardial infarction," Current Vascular Pharmacology, vol. 13, no. 1, pp. 26-36, 2015.

[12] Y. Wang, P. Lu, D. Zhao, and J. Sheng, "Targeting the hedgehog signaling pathway for cardiac repair and regeneration," Herz, vol. 42, no. 7, pp. 662-668, 2017.

[13] G. Xiong, W. Ji, F. Wang et al., "Quercetin inhibits inflammatory response induced by LPS from Porphyromonas gingivalis in human gingival fibroblasts via suppressing NF-kappaB signaling pathway," BioMed Research International, vol. 2019, Article ID 6282635, 10 pages, 2019.

[14] W. Yi, Y. Wen, F. Tan et al., "Impact of NF- $\kappa$ B pathway on the apoptosis-inflammation-autophagy crosstalk in human degenerative nucleus pulposus cells," Aging, vol. 11, no. 17, pp. 7294-7306, 2019. 